\title{
Study of Eimeria canadensis in Bos indicus from Marathwada Region
}

\author{
V. K. Bansode ${ }^{1}$, S. V. Nikam ${ }^{2}$, S. R. Sable \\ Dept.of Zoology Dr. Babasaheb Ambedkar Marathwada University, Aurangabad (M.S.)
}

\begin{abstract}
The objective of this study is first time describe Eimeria canadensis in cow. Bos indicus from Marathwada region. The described Eimeria canadensis, common to cattle have not been reported previously from Bos indicus in this region.
\end{abstract}

Keywords: Bos indicus, Coccidiosis, Eimeria, Sporulated oocyst and Unsporulated oocyst

\section{Introduction}

Coccidiosis in cattle is one of the five most economically important diseases of the cattle industries. Eimeria are known to infect cow. Several eimeria species are pathogenic in cattle causing several clinical symptoms (Samson Himmelstjerna et al 2006, Sanchez, Romero, Foundroge 2008). Most pathogenic species in cow is Eimeria zurnii and Eimeria bovis.

In severe infection deaths occur within 7 to 10 days. In united state 2 to 3 millions cattles are treated annually, for clinical coccidiosis.It is reported that up to one in five of these animals dies. Eimeria Canadensis are studied and identified in different countries (Kasim, Al Shawa 1985, Munyua, Ngotho1990 Chivonda et al 1997, Matjila, Penzhorn 2002, sanchez, romero, Founroge 2008.

Several species of coccidia cause extensive pathological damage and mortality in poultry, cattle, sheep, goat, pig and other domestic animals. For this reason coccidia have attracted the attention of many workers. Here author is describing only one species i.e. Eimeria Canadensis

\section{Materials and Methods}

The material for the study of species Eimeria canadensis in cow (B. indicus) was obtained from different localities in Marathwada region in the form of fecal matter. Fecal matter of each cow was collected in separate plastic vials. These samples were examined and processed within five to six days after collection. Used salt flotation tech. for the presence of oocyst after sieving and centrifugation. The oocysts collected were spread out in shallow petridishes in $2.5 \%$ potassium dichromate solution for sporulation. The character included ware oocyst shape, presence or absence of micropile, polar granules and oocystic residiuum. Similarly for sporosysts its shape, steida body, residiuum and sporulation time was taken to consideration.

\section{Description of the oocyst}

The oocysts of this species are ovoid. Micropyle is inconspicuous and micropylar cap is absent. The wall of

oocyst is two layered 1 to $1.5 \mu \mathrm{m}$ thick. Outer layer is thicker than inner layer. Inner layer is light red and outer one is reddish brown. The unsporulated oocyst has spherical to ovoidal, sporoblast at the centre in the form of compact mass. The sporulated oocyst shows four sporocysts. No oocystic residiuum is seen. Sporocystic residium is in the form of loose granules in linear masses. Sporozoites are elongated, banana shaped and lie head to tail in the sporocyst and have two to three clear refractile globules each. Steida body is very clear.

\section{Dimension of sporulatedoocysts are as follows:-}

(All measurements are in $\mu \mathrm{m}$ ) \{Phase contrast at 100x X $10 \mathrm{x}$ \}

\begin{tabular}{|l|l|l|}
\hline \multicolumn{1}{|c|}{ Particulars } & \multicolumn{2}{c|}{ Oocyst from cow feces } \\
\hline Length of oocyst & $29-33$ & 31 \\
\hline Width of oocyst & $23-26$ & 24.5 \\
\hline L/W ratio of oocyst & 1.26 \\
\hline Length of sporocyst & $16-18$ & 17 \\
\hline Width of sporocyst & $05-07$ & 06 \\
\hline L/W ratio of sporocyst & 2.83 \\
\hline
\end{tabular}

\section{Sporulation time:}

Sporulation time of the oocyst was 4-5 days.

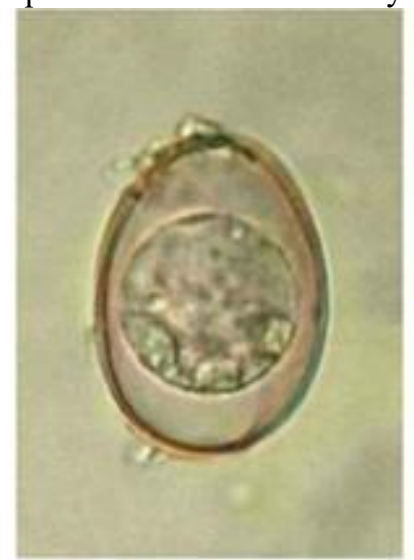

Unsporulated

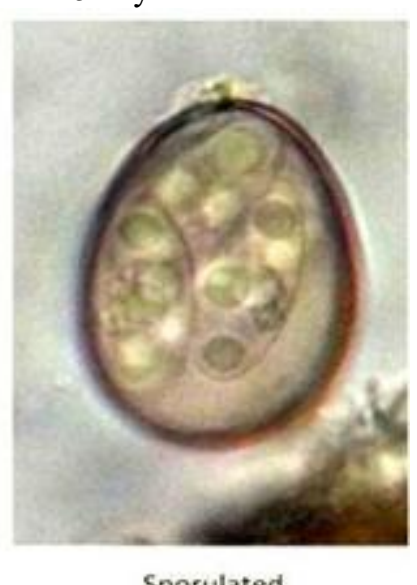

Sporulated 


\section{International Journal of Science and Research (IJSR) \\ ISSN (Online): 2319-7064}

Index Copernicus Value (2013): 6.14 | Impact Factor (2014): 5.611

Showing the Comparative Dimension of Oocysts of Eimeria canadensis from Cow (Based on Various Authors)

\begin{tabular}{|c|c|c|c|c|c|c|c|c|c|c|c|c|c|c|c|c|c|}
\hline \multirow{2}{*}{$\begin{array}{l}\text { Sr. } \\
\text { No. }\end{array}$} & \multirow{2}{*}{ Author } & \multicolumn{2}{|c|}{$\begin{array}{c}\text { Ooocyst } \\
(\mu \mathrm{m})\end{array}$} & \multirow{2}{*}{ average } & \multirow{2}{*}{$\begin{array}{c}\text { length / } \\
\text { width } \\
\text { ratio }\end{array}$} & \multirow[t]{2}{*}{$\begin{array}{c}\text { microp } \\
\text { yle }\end{array}$} & \multicolumn{2}{|c|}{$\begin{array}{l}\text { Sporocyst } \\
(\mu \mathrm{m})\end{array}$} & \multirow{2}{*}{ average } & \multirow{2}{*}{$\begin{array}{l}\text { length } \\
\text { width } \\
\text { ratio }\end{array}$} & \multirow{2}{*}{$\begin{array}{c}\text { Oocyst } \\
\text { wall } \\
\text { thickness }\end{array}$} & \multirow{2}{*}{$\begin{array}{c}\text { Oocysticre } \\
\text { sidium }\end{array}$} & \multirow[t]{2}{*}{\begin{tabular}{|c} 
Sporo \\
cysticresi \\
dium
\end{tabular}} & \multirow[t]{2}{*}{$\begin{array}{c}\text { Shape of } \\
\text { sporozoit } \\
\text { e }\end{array}$} & \multirow[t]{2}{*}{$\begin{array}{c}\text { Steid } \\
\text { a } \\
\text { body }\end{array}$} & \multirow{2}{*}{$\begin{array}{c}\text { Refractil } \\
\text { e } \\
\text { globule }\end{array}$} & \multirow{2}{*}{$\begin{array}{c}\text { Sporula } \\
\text { tion } \\
\text { time }\end{array}$} \\
\hline & & $\begin{array}{c}\text { Leng } \\
\text { th }\end{array}$ & $\begin{array}{c}\text { Wid } \\
\text { th }\end{array}$ & & & & $\begin{array}{l}\text { Leng } \\
\text { th }\end{array}$ & Width & & & & & & & & & \\
\hline 1 & \begin{tabular}{|c|} 
Nigeria \\
research \\
report \\
2004 \\
parts of \\
Plateau \\
State
\end{tabular} & $\begin{array}{c}29.1 \\
-36.2\end{array}$ & $\begin{array}{c}21.0 \\
- \\
26.2\end{array}$ & $\begin{array}{c}32.65 x \\
23.6\end{array}$ & 1.38 & $\mathrm{P}$ & 18.3 & 7.6 & $18.3 \times 7.6$ & 2.40 & 0.6 & $\mathrm{Ab}$ & $\mathrm{Ab}$ & Elongate & - & $2-3$ & $3-5$ \\
\hline 2 & $\begin{array}{c}\text { M.A.Tay } \\
\text { lor,R.L. } \\
\text { Coop,R. } \\
\text { L.Wall ( } \\
\text { E.book : } \\
\text { Vaterinar } \\
\text { y } \\
\text { Parasitol } \\
\text { ogy) }\end{array}$ & $\begin{array}{c}28- \\
37\end{array}$ & $\begin{array}{c}20- \\
22\end{array}$ & $\begin{array}{c}32.5 \times 2 \\
1.0\end{array}$ & 1.54 & $\mathrm{P}$ & $\begin{array}{c}12- \\
22\end{array}$ & $6-10$ & $17.0 \times 8.0$ & 2.12 & - & $\mathrm{P}$ & $\mathrm{P}$ & - & $\mathrm{P}$ & $2-3$ & $3-4$ \\
\hline 3 & \begin{tabular}{|c} 
Brian \\
Lassen \\
2009 \\
Estonian \\
Universit \\
y of Life \\
Sciences
\end{tabular} & $\begin{array}{c}28- \\
37\end{array}$ & $\begin{array}{c}20- \\
27\end{array}$ & $\begin{array}{c}32.5 \times 2 \\
3.5\end{array}$ & 1.38 & $\mathrm{P}$ & $\begin{array}{c}15- \\
22\end{array}$ & $6-10$ & $18.5 \times 8.0$ & 2.31 & - & - & $\mathrm{P}$ & - & $\mathrm{P}$ & - & - \\
\hline 4 & \begin{tabular}{|} 
Institute \\
of \\
Parasitol \\
ogy \\
Univerait \\
y of \\
Leipzing
\end{tabular} & $\begin{array}{c}28- \\
37\end{array}$ & $\begin{array}{c}20- \\
27\end{array}$ & $\begin{array}{c}32.5 \times 2 \\
3.5\end{array}$ & 1.38 & $\mathrm{P}$ & - & - & - & - & - & $\mathrm{Ab}$ & $\mathrm{P}$ & - & - & - & - \\
\hline 5 & $\begin{array}{c}\text { Zoologic } \\
\text { al } \\
\text { Survey } \\
\text { of India } \\
1980 \text { by } \\
\text { A.K.Man } \\
\text { dal }\end{array}$ & $\begin{array}{c}25- \\
37\end{array}$ & $\begin{array}{c}18- \\
28\end{array}$ & $\begin{array}{c}31.0 \times 2 \\
3.0\end{array}$ & 1.34 & $\mathrm{P}$ & $\begin{array}{c}13- \\
17\end{array}$ & $\begin{array}{l}6.6- \\
8.9\end{array}$ & -- & 1.93 & 1.2 & $\mathrm{Ab}$ & $\mathrm{P}$ & Elongated & $\mathrm{p}$ & 1 & $3-4$ \\
\hline 6 & $\begin{array}{c}\text { Vasant } \\
\text { Jadhav } \\
2002\end{array}$ & $\begin{array}{c}25- \\
38\end{array}$ & $\begin{array}{l}17- \\
25\end{array}$ & $\begin{array}{c}31.5 \times 2 \\
1.0\end{array}$ & 1.5 & $\mathrm{P}$ & $\begin{array}{c}13- \\
18\end{array}$ & $6-9$ & $15.5 \times 7.5$ & 2.06 & 1.2 & $\mathrm{Ab}$ & $\mathrm{P}$ & $\begin{array}{l}\text { Banana } \\
\text { shape }\end{array}$ & $\mathrm{P}$ & $2-3$ & $3-4$ \\
\hline 7 & $\begin{array}{c}\text { Bhatia } \\
\text { et.al } \\
1968\end{array}$ & $\begin{array}{l}25- \\
37\end{array}$ & $\begin{array}{l}18- \\
28\end{array}$ & $\begin{array}{c}31.0 \times 2 \\
3.0\end{array}$ & 1.34 & - & - & - & - & - & - & - & $\mathrm{P}$ & - & - & - & - \\
\hline 8 & $\begin{array}{c}\text { Levine } \\
\text { and } \\
\text { Ivens } \\
1970\end{array}$ & $\begin{array}{c}28- \\
38\end{array}$ & $\begin{array}{c}20- \\
29\end{array}$ & $\begin{array}{c}33.0 \times 2 \\
4.5\end{array}$ & 1.32 & - & - & - & - & - & - & - & - & - & - & - & - \\
\hline 9 & \begin{tabular}{|c|} 
Pellerdy \\
1974
\end{tabular} & $\begin{array}{l}28- \\
37\end{array}$ & $\begin{array}{l}20- \\
27\end{array}$ & \begin{tabular}{|c|}
$32.5 \times 2$ \\
3.5
\end{tabular} & 1.38 & - & - & - & - & - & - & - & - & - & - & - & - \\
\hline 10 & $\begin{array}{c}\text { Present } \\
\text { author }\end{array}$ & $\begin{array}{l}29- \\
33\end{array}$ & $\begin{array}{c}23- \\
26\end{array}$ & \begin{tabular}{|c|}
$31.0 \times 2$ \\
4.5
\end{tabular} & 1.26 & $\mathrm{P}$ & $\begin{array}{l}16- \\
18\end{array}$ & $05-07$ & $17.0 \times 6.0$ & 2.83 & 1.5 & $\mathrm{Ab}$ & $\mathrm{P}$ & Elongated & $\mathrm{P}$ & $2-3$ & $4-5$ \\
\hline
\end{tabular}

\section{Results and Discussion}

This species was first described by Bruce 1921 in united state. Later described by several workers as Christensen 1941, Levine and Ivens 1967. Kennedy and Kralka 1987, worked on eimeria in Alberta,Canada. Lin et al.1993 worked in China.

In Turkey Dumanli et al. 1993 worked on incidence of coccidia species. Card 1993 and Grommes 1996 worked on epidemiological study of Eimeria infecting among grazing calves.
In India various workers reported this species from different parts of India like Gill 1960, Patnaik1963, Patnaik and Pande 1965 and Bhatia et.al 1968.

Present author compared the species with earlier workers is shown in above table. After observation it is seen that approximately all the oocyst are similar including the present species except slight morphometric differences.

In Levine the oocysts are slightly larger than present one V.D.Jadhav observed small polar granule which is not observed here. Sporocystic residium is absent in Plateau State which is seen in the present species though some minor variations are seen in the earlier species and the present species. 


\section{International Journal of Science and Research (IJSR) \\ ISSN (Online): 2319-7064 \\ Index Copernicus Value (2013): 6.14 | Impact Factor (2014): 5.611}

Micropyle is noted by all the workers including present author except Bhatia et al 1968, Levine and Ivens 1970, Pellerdy 1974.

Sporocystic residium is in all the earlier species except Nigeria research report which is present in present species. Oocystic residium absence in all species including present one except M.A.Tylor, R.L Coop and R.L.Wall.

Sporulation time is approximately similar in all including present species. It is concluded that the present species is Eimeria Canadensis as most of the characters are similar and redescribed here by present author.

\section{Conclusion}

Present author compared the present species with the species Eimeria Canadensis described by earlier workers as in above comparative chart. It is concluded that though there are minor morphometric differences the species is Eimeria Canadensis and redescribe here.

\section{Acknowledgment}

The authors are grateful to the Head,Dept.of Zoology Dr. Babasaheb Ambedkar Marathwada University, Aurangabad for his kind cooperation encouragement and facilities extended.

\section{References}

[1] Abebe, R., Wossene, A., Kumsa, B. (2008). Epidemiology of Eimeria infections in calves in AddisAbaba and Debre-Zeit dairy farms, Ethiopia. International Journal of Applied Research in Veterinary Medicine 6, 24-30.

[2] Abisola Titilayo,Oluwadare. (2004). Studies on Bovine coccidia [Apicomplexia: eimeriidae] in parts of Plateau State, Nigeria.( http://dspace.unijos.edu.ng/jspui/handle/123456789/129 ).

[3] Arslan, M., Tuzer, E. (1998). Prevalence of bovine eimeriosis in Thracia, Turkey. Turkish Journal of Veterinaryand Animal Sciences 22, 161-164.

[4] B. A. Pandit. (2009). Prevalence of Coccidiosis in Cattle in Kashmir valley. Vet Scan 2009 Vol 4 No 1.

[5] B.L.Penzhom, S.E.Knapp and C.A.Speer. (1994). Enteric Coccidia in Free-ranging American Bison (Bison bison) in Montana. Journal of Wild life Diseases, 30 (2), 1994, pp.267-269.

[6] Brian Lassen (2009). Diagnosis, Epidemiology and Control of Bovine coccidioses in Estonia.

[7] Brian Lassen, Leena Seppa-Lassila. 2014.Recovery and Sporulation of Bovine Eimeria oocysts after Exposure to Sub-Zero Temperature. ISSN 1392-2130. Veterinarija Ir Zootechnika (Vet Med Zoot). T. 66 (88). 2014

[8] Cicek, H., Sevimi, F., Kozan, E., Kose, M., Eser, M., Dogan, N. 2007. Prevalence of coccidia in beef cattle in western Turkey. Parasitology Research 101, 12391243.
[9] Cornelissen, AWCA., Verstegen, R., Vanden-Brand, H., Peri, NM, Eysker,M., Lam, TJGM., Pijpers, A.1995. An observationalobservational study of Eimeria species in housed cattle on Dutch dairy farms. Veterinary Parasitology 56,7-16.

[10] Daugschies, A., Najdrowski, M.2005. Eimeriosis in cattle: current understanding. Journal of Veterinary Medicine B 52, 417-427.

[11] Dawid, F., Amede, Y., Bekele, M. 2012. Calf coccidiosis in selected dairy farms of Dire Dawa, Eastern Ethiopia. Global Veterinaria 9, 460-464.

[12] Dong, H., Zhao, Q., Han,H., Jiang, L., Zhu, S., Li, T., Kong, C.,Huang, B. 2012. Prevalence of coccidial infection in dairy cattle in Shanghai, China. Journal of Parasitology 98, 963-966.

[13] Gill, B.S. (1960): The coccidian oocysts of Indian cattle. pp. Proc. 47 th session Ind. Sci. Cong. Section YIl: 430.

[14] Heidari, H., Sadeghi-Dehkordi, Z., Moayedi, R., Gharekhani, J. 2014. Occurrence and diversity of Eimeria species in cattle in Hamedan province, Iran. Veterinarni Medicina, 59, 2014 (6): 271-275.

[15] Heidar Heidari, Jamal Gharekhani. 2014. Detection of Eimeria species in Iranian native cattle. International Journal of Advanced Research (2014), Volume 2, Issue 7, 731-734.

[16] Kasiman, A.A., Al-Shawa,Y.R.1985. Prevalence of Eimeriain faeces of cattle in Saudi Arabia. Veterinary Parasitology 7, 95-99.

[17] Kennedy, M.J., Kralka, A.1987. A survey of Eimeria spp.in cattle of Central Albertia. The Canadian VeterinaryJournal 3, 124-125.

[18] Klockiewicz, M., Kaba, J., Tomczuk, K.,Janecka, E., Sadzikowski, A.B., Rypula, K., Studzinska, M., Malecki-Tepicht, J.2007. The epidemiology of calf coccidiosis (Eimeria spp.) in Poland. Parasitology Research 101, 121-128.

[19] Nikam,S.V.2011. Protozoology. Oxford book company,Jaipur, NewDelhi.

[20] Nikam,S.V. and Borde,S.N.2013. A textbook of Practical Zoology Protozoa and Helminths, Dama international publication Solapur Maharashtra India.

[21] Paul Tshepo Matjila. 2000. Occurrence and diversity of Bovine coccidia at three localities in South Africa. Department of Veterinary Tropical Diseases Faculty of Veterinary Science University of Pretoria Pretoria

[22] Pilarczyk, B., Balicka-Ramisz,A., Ramisz,A.2000. Studies in coccidiosis in cattle in Northwest Poland. Electronic Journal of Polish Agricultural Universities 3, 101-103.

[23] Rahmeto, Abebe, Abebe, Wossene., Bersissa, Kumsa., 2008. Epidemiology of Eimeria Infections in Calves in Addis Ababa and DebreZeit Dairy Farms, Ethiopia. Intern J Appl Res Vet Med, Vol. 6, No. 1, 2008.

[24] Nalbantoglu,S., sari, B., Cicek,H., Karaer,Z. 2008. Prevalence of Coccidian Species in the Water Buffalo (Bubalus Bubalis)in the Province of Afyon, Turkey. ACTA VET. BRNO 2008, 77: 111-116; doi:10.2754/avb200877010111.

[25] Yakhchali, M., Zarei,M.R.2008. A survey of frequency and diversity of Eimeria species in cattle and 


\section{International Journal of Science and Research (IJSR) \\ ISSN (Online): 2319-7064}

Index Copernicus Value (2013): 6.14 | Impact Factor (2014): 5.611

buffalo in Tabriz region (in Persian). Iranian Veterinary

Journal 4, 94-102.

\section{Author Profile}

Vikas K. Bansode is Ph.D Scholar, Dept. of Zoology Dr. Babasaheb Ambedkar Marathwada University, Aurangabad. 431001 (M.S) India. Working under the guidance of Dr. Nikam S.V. from last 3 years.

S. V. Nikam is professor (Retired) in Dept. of zoology Dr. Babasaheb Ambedkar Marathwada University, Aurangabad. 431001 (M.S) India. She is specialized in parasitology and has 100 research papers to her credit in national and international journals and also two books prescribed for UG/PG Student.

S. R. Sable is Ph.D Scholar, Dept. of Zoology Dr. Babasaheb Ambedkar Marathwada University, Aurangabad. 431001 (M.S) India. Working under the guidance of Dr. Nikam S.V. from last 3 years. 